\title{
Creative Drama in Support Therapies for Children with Learning Disorders
}

\author{
Dana Kollárová ${ }^{*}$
}

\begin{abstract}
The paper familiarizes the reader with the output of the project titled Support Therapies for Children with Learning Disorders which we implemented at an elementary school. It describes the individual therapy types which were used and which can, to certain extent, help the pupils with special educational needs. The paper focuses on our experiences with the use of creative drama elements and drama therapy with $5^{\text {th }}-9^{\text {th }}$ grade pupils. It presents the acquired qualitative data which show the reader the specifics of the educational process and public presentation of pupils with learning and behaviour disorders.
\end{abstract}

Key words: creative drama, drama therapy, role play, movement and pantomime, improvisation.

\section{Introduction}

In the school year 2010/2011, we had the opportunity to cooperate with the elementary school Podzámska in Hlohovec in the project Support Therapy for Children with Learning Disorders which was supported by the Open Society Foundation (OSF). The Faculty of Education of Constantine the Philosopher University in Nitra participated in workshops in the sphere of drama therapy, the creative process which resulted in stage formation. At all the meetings we worked with pupils of lower secondary level of education, involving schoolchildren with special educational needs. In many cases pupils from socially non-stimulating or "disturbed" family environment, but mainly with weaker communication skills, were involved. In the process we used the methods and techniques of creative drama and drama therapy; the core activities, processes and reflexions of which are presented in the paper. At the meetings within the therapies, the importance of having not more than three classmates in one group was emphasized and meetings regularly took place in an environment different from the classroom.

* Dana Kollárová, Constantine the Philosopher University in Nitra, Nitra, Slovakia; dkollarova@ukf.sk 
Creative drama is rather rarely used in the educational process. However, if we want to see its benefits in education, there must be a systematic approach of a teacher. Therefore we used the opportunity to work with these pupils to make them relax, to make them talk about their interests, and to search, find and develop themselves. First of all, they needed to get rid of barriers in communication and not to be afraid to ask if they do not understand.

\section{Through the steps of creative drama to confidence in communication}

The term creative drama in the school context started to emerge with the aim to penetrate into the educational process by its methods and techniques. In most British schools the procedures of creative drama are completely understood and they are being integrated into all the schools. C. O'Neill sees drama in education (1998) as a way of learning. The author claims that "through the pupils' active identification with an imaginary role and situation in drama, they can learn and explore controversial issues, events and relationships". K. Blahová (1996) points out that "in case of application creative drama (or its synonym drama education, educational drama, drama at school, staging, education by drama) at school, it cannot be seen as tragic or nerve-wracking event, but it must be seen as a moment where a person decides to act and chooses the way of action". During education, a teacher works with pupils' psyche, their acting conditioned by the principles of learning. S. Kot'áková (2008) takes the view, that by creative drama in children we can develop:

- confidence and creative expression

- emotional stability

- physical coordination

- beneficial life philosophy

The purpose of the methods of creative drama is to simulate drama situations. Real environment or literary stimulus may serve as a source of inspiration for the teacher. The basic method of creative drama is role play. Entering a role requires knowledge of the situation to be role played by pupils, they interpret it (by words, movements) as they understand it or how they explain it to themselves and decide on how they would act in a particular life situation. The mentioned steps lead to improvisation or to a dramatic game. The dramatic game is about group experience in which we encourage pupils to express themselves in a group activity (in which they must follow the rules set together) or possibly, to express ways of decision making and acting of somebody else. Thus, dramatic game can be understood as an activity in which pupils role play situations of everyday life by which they learn how to communicate and how to solve problems, how to gain confidence in communication. Pupils learn that rules must be followed in 
order to solve problems and to recognize the possible consequences of a wrong decision or acting. At the same time, by using this approach pupils learn to take responsibility for their decisions and actions. In relation to the curriculum, dramatic game plays an important role as pupils express phenomena and concepts related to the curriculum by means of movement, words, sound, and deployment of objects in a room. It gives feedback to a teacher on whether pupils understand new concepts, content, and topic. We can talk about the method of creative drama as the basic method of communication game. Thus, the principle of the stated approach is entering into roles (of somebody, of something). The notion of role in terms of creative drama at school has been defined by J. Valenta (1995) as "a teaching task usually requiring internal (behaviour and action) visualisation of a particular phenomenon based on the inner vision and experiencing of the phenomenon". It is necessary to mention that in creative drama the creative process is always in the first place, it is not the final effect (!). In the creative process, all the players participate in the game; there should not be any hands-off observers. The content of creative drama includes satisfying of social needs of a child among which the most important one is the need for communication, the need to talk and to be heard, the need of being accepted, to belong somewhere, a positive response to every positive action, the need to experience success, and to handle with failure.

According to the stated views we can conclude that creative drama (dramatic education) plays an important role in education and developing the personality of a child, it teaches a child how to understand itself, how to cooperate with the surrounding environment, how to behave with empathy, and how to express feelings and develop emotionally.

\subsection{Creative drama as a part of drama therapy}

It is gratifying that we can see the methods of creative drama in relation to the educational process at school more and more frequently. Miron Zelina (2000) attributes to drama education (creative drama) at school a significant importance in the development of the emotional sphere. According to him, thanks to drama education a child/pupil learns how to correct the feelings in pursuance of recognition, monitoring and experiencing situations with other children. Furthermore a child learns how to control his/her emotional expressions. It may be, for example, when children lose something. Children learn how to deal with feelings when they face new facts, phenomena, stories, to which they have not had any opportunity to express their feelings yet. By all these means children develop their emotional side. In this context the results of an extensive research that D. Goleman (1997) mentions in the book Emotional intelligence are interesting because the topicality of the research results is confirmed in current pedagogical practice. The research results show that this generation of children has significantly more emotional problems than previous generations. They suffer from loneliness and depression more often, they are shyer and more 
disobedient, more impulsive and more aggressive, are likely to worry more than their parents or grandparents. Therefore, it is necessary to place the emphasis on the selection of didactic methods by the use of which a teacher can improve the educational process so that he/she supports the development of the whole personality of a pupil. However, this requires a well-prepared teacher in both professional and personal aspects with courage to think and create, someone who is able to connect the mind and the heart of a pupil.

Currently, at school there are many pupils requiring special educational procedures. We dare to say that one of the possibilities how we can eliminate this problem is that a teacher will, based on self-reflection, discover and search opportunities of applying activating methods in education. The methods of creative drama can be considered activating methods of education. However, if we talk about the application of the methods of creative drama in relation to pupils with special educational needs, we can talk about drama therapy. We realize that it is mostly used by psychotherapists or special pedagogues but we cannot exclude that games, exercises and improvisation may be used in the pedagogical work of a teacher who is professionally oriented and has long experience with creative drama in the educational process (preferably also with an interest in art activities) and who has the ability to recognize the interests, needs and difficulties of children/pupils. In the school context we would rather talk about drama therapy not as a form of treatment but as a form of art - art of playing, communicating, perceiving, experiencing and creating. According to Jennings (Valenta, 2001) creative artists are, to some extent, included in drama therapy.

Drama therapy is a medical and an educational method. We can use it with individuals or with small groups. M. Barham (1995) considers drama therapy as art, a medical and an educational method applicable in individual and in group work. According to him it is the intentional use of drama and theatrical processes with the aim to reach therapeutic targets such as symptom relief, emotional and physical integration and personal growth. K. Majzlanová (2000) understands its usage rather widely, especially with learning disorders, behaviour, speech or emotional problems as well as in work with abused, neglected and disabled children. Mostly, we meet the procedures of drama therapy in pedagogical and psychological counselling, in diagnostic centres for children, in psychiatric facilities, in drug addiction centres, in some school facilities, in non-profit counselling organization, but also in senior facilities. The principle of drama therapy is very aptly expressed by R. Emunach (Majzlanová, 2004) who claims that "we do not tear down the walls of players, we only try many door handles and we search where and for whom they will open." Here we can see the compliance with the statement above - the core is in the creative process and in searching, discovering, trying, or applying in real life. In drama therapy, as in other types of therapies - bibliotherapy, occupational therapy, and 
music therapy - we can talk about the approach to education with a medical and an educational focus.

\section{Experience with application of drama therapy elements with pupils with learning and behavioural disorders}

We can say that the group of children/pupils that we had the opportunity to realize workshops with regularly within the project Support Therapies for Pupils with Learning Disorders persuaded us by its approach that all the meetings had their meaning. Even pupils not considered to be very smart by their teachers and classmates were able to demonstrate:

- aesthetical feeling (also in communication),

- greater confidence in application of their own skills

- they realized that they are a part of a group, in which more people communicate and it is necessary to listen to them and respect diversity of opinions

- they were able to appreciate the results of teammates

- they were gradually learning how to follow the rules, they understood that every game (also a simulated situation) similarly as work, has its rules, it carries expectations, and it has its beginning and end.

Based not only on the realized project but on a several-year school practice and research work we dare to claim that the use of the methods of creative drama may show pupils and teachers the way to learn to perceive the world, to think about it and to make a relationship to it.

The introductory exercises with pupils led to some elementary activities and games which were focused on warming up, relaxation, and concentration. We recommend including these exercises at the beginning of meetings (classes). They are also suitable in situations when pupils' attention is decreasing. Exercises are useful not only for skill acquisition and development, skills are important for everyone of us, but are also used to create the necessary atmosphere. We can develop further work on them. Warm up or "playing" has a significant influence on our psyche. K. S. Stanislavskij (1997) who devoted to work and expression of an actor attributes to total relaxation a high importance. He took the view that muscle tension disturbs psychical work and expression. During physical tension, there cannot be any talk about normal expression of a role. The author claimed that "the most sensitive" constriction at same point, which we do not immediately notice, may have a destructive effect on creative work. Therefore for children it is important to learn how to relax muscle tension and control the state of relaxation constantly. This process of self-observation and relaxation of the excessive tension should gradually become a mechanical habit. For this we must work daily and systematically. 
It is necessary to say that the first meeting was not only about introduction but also about reminding and explaining the importance of rules, shouting over, suspicion - when somebody was looking at somebody else they believed that there was a bad intention. Children were not used to talk in a circle, so they were obstructed by the view of their schoolmates. All children were interfered with by the eye contact during exercises. It was visible during the game when they had to gain new information about their teammates. The principle of the game was to walk freely in the room with closed eyes. At the signal they had to open their eyes and get new information from the nearest teammate - ask them about something quickly - about family, school, housing, friends, and interests while they had to keep the eye contact and remember the information. The gained information and the questions used by children with the intention to get the information were surprising but several of them proved that the children need a specific approach to education.

Similarly, we started with exercises from self-awareness, awareness of own inner space, gradually moved to the awareness of the external space and then to exploring group work (with respect to the partners), and finally to the perception of group sensitivity. At the beginning, the exercises and games were problematic for children, it was influenced by the above stated factors in relation to the risks related to the first experience with creative drama. During play with an object, later during play with sounds, children gained greater confidence because they were realising that classmates who were next to them were not the ones to make fun of them when they express an opinion. It could be seen in short improvisation games. For example, they made up a "sound" story from the sounds they heard when their eyes were closed. Based on different sounds in the interior or in the nature which they were able to identify and assign meaning to them, they were able to create an activity or feature by unarticulated sounds breaking of a glass, tearing of a cloth, the sound of the brook, etc. The first "easy" job with the group was creation of a calm atmosphere during telling own stories which they could "see" thanks to the improvised sounds made by the teacher inside the room by means of contact with different objects.

We know from experience that every beginning with creative drama at school brings mostly complications (disrespect of a group, space, game rules, shame, lack of relaxation, doubts, ridicule, inclination to compare with others) what discourages teachers. It is necessary to remind children several times that everybody is different, unique, original, and during a creative activity no one is better or worse than the others. We explained to pupils that our activity needs relaxation, concentration, sense perception, our imagination, fantasy, our movement, speech skills, and memory as well as logical and strategic thinking. Everything should have the same denominator creativity. We ensured children that they could express their opinions at meetings, they would be heard, not mocked and we would certainly deal with them. 
At the next meeting children asked for some of the games we used as first. In the group it was necessary to gain and keep trust, to follow the rules, to concentrate. They showed a huge interest in the game of mirrors in which they had to use not only their observation skills but also to concentrate, and what was the most difficult for them, they had to respect the opinions of a teammate. As they showed interest in blind games and they were relaxed, we included more of these activities because then they had the opportunity to work in pairs. We, furthermore, found the interest of pupils in improvisation in the game of guiding puppets where they verified the contact, respect and mutual interplay. They pretended to pull the strings of a puppet (knees, hands, turning its head, feet and shoulders) and moved it to another place. Here, they bore responsibility for a teammate and vice-versa, the teammate had to trust somebody. In relation to this exercises with puppets or any play with objects that can be used in puppet (object) theatre, according to B. Kováčová (2001) it is necessary to mention that the whole process of the drama activity with puppets is in preparation and presentation testing with an emphasis on the process of inner experience and identification. During play with an object (also when we make object theatre e.g. from the objects that are close to us) the participants do not need to have any experience with animation with puppets. It is a creative form of interpretation using words and motion.

In nonverbal communication with children we tried mimics and gestures first then we continued with communication in space and with the elements of pantomime. The interest of students was gained by motion etudes, their task was to play e.g. invitation to the cinema, express the title of a movie by motion. By means of improvisation and games we wanted children to tell us something about their feelings, desires. We did it through "reincarnation" into objects, by role play (we played something) - children played colours, animals, furniture, movie characters, food, but also vehicles.

One meeting was devoted to association games - sound, auditory, motion. After the third meeting we focused improvisation, games and exercises on the topic Circus because we planned to perform on the theatre show but children did not know about it. We played a game titled according to the circus which should had come. Children had to give names to the actors. By motion improvisation we made circus figures - acrobatic elements, which they should present in front of a group of teammates. They were preparing in groups of two or three players. It was a pleasure to see their cooperation and respect for opinions. They suggested the following disciplines: an acrobat with an acrobatic figure, throwing a ball in pairs - a ping pong ball, a tennis ball, a medicine ball, a balloon and they had to express the weight, tempo and rhythm of the falling ball. They did not forget about a clown in the circus and they prepared a word-motion etude. Later on, they suggested the clown to introduce the circus figures and their activities $a$ weightlifter, a faquir, a knife thrower, juggling, holding plates on a stick. Children created beautiful things from a piece of cloth, at the last meeting one 
piece of a cloth was enough to make a barbell for a strongman, a crow, a snail, a pump, a bat and so on, without mutual ridicule. They took the responsibility and they showed ability to finish exercises and to explain their suggestions. Similarly, as we continued in work with an object (to make something else of it), they were not afraid of word improvisation which we connected to our game in the space.

A chair was an inspiration for them and after standing on it they expressed their ideas - rhymes. Naturally, we were interested in the problems they struggle with. We played the game What burns you. The main principle of the game was to sit on a hot chair. They could not sit on it for very long, therefore they told what troubles their soul quickly. The most frequent answers were - bad marks from Maths, exams from Slovak language, bad marks, and school. But not only the school bothered them, they expressed that their troubles are: everything, but also obloquy of a teammate - "he is provoking me by his existence". We ensured them that life is not only marks, and the fact that we want to learn something that we understand is important. We did not forget to remind, that everybody is different and everybody is interested in different things, we express ourselves differently. Consequently, I used a chair and I expressed what is burning me we sometimes do not follow the rules and we do not listen to each other.

One of the meetings was devoted to motion and pantomime. For example, there were pantomimic expressions of the surrounding objects, diverse simulated situations from the real life environment. The greatest experience was improvisation on the theme Meeting, or What should I expect of it? Children made up situations by themselves what is admirable and we can consider it their inner advance in comparison to the beginning of the creative activity.

Naturally, we cannot say that all the exercises, games and improvisation were without any difficult educational situations at the beginning. We must admit, that inadequate and sometimes aggressive behaviour of a group of children occurred. An example of one of the above mentioned situations was the advice: "Hit her with a waddy!" This was, unfortunately, the most common form of the children's communication what was reflected their relationship to other people, family and in school environment. For motion improvisation it was typical that they wanted to repeat activities at every meeting and they always came up with new ideas. It was the proof of the fact that children were interested in the applied form of education. We did so as we saw progress. When we wanted to calm the children down, we included narrative pantomime (a player expresses a situation by movement). In such exercises children felt how our body works and they were able to get rid of psycho-physical stress.

It was a problem to express oneself by a correct sentence construction in this group of children. Therefore we made it easier by dabbing game. The children did not want to use words because they interpreted them as a barriers and thus we chose our own language - it was the cluster of articulated sounds which have no meaning, they are not words. Our own language could be captured by the 
dynamics and intonation of "the words" we were using. For the pedagogue it was important that children were able to listen, watch, and mutually react to each other, they understood the dynamics of speech, were able to decipher its meaning and results in social communication. The emphasis was in this case laid on motion expression and intonation as well as capturing the ideas of the two actors.

We consider a positive aspect of the work with this group of children that they were able to work in pairs, make agreements and respect each other. We can give the following example of the work in pairs: pupils were asked to make up one sentence which would capture the relationship of two objects that had been chosen. In this improvisation children did not want to express verbally in spite of the fact that their task was to say a sentence. However, we must appreciate, that they expressed excellent ideas by means of movement:

- A book and a shelf - the covering sentence: "Nobody buys me."

- A handle and a window: - the covering sentence: "It is not working! I want fresh air! Call 112!"'

At the beginning it was a problem as the children were afraid of working with imagination, they wanted to play objects. They also had a problem to talk about objects (e.g. a book) and the role of a book and a shelf (I am a book, I talk about myself, the children talk about themselves).

We regularly included activities for stress and relaxation - we were walking along the night city - we included a walk by tempo and rhythm of a tambourine, their task was to identify steps - a dog, a door, somebody is on the run, etc. It is important to realize what is happening with us when we are in stress and when we are relaxed for better understanding of ourselves.

In activities which led to the development of the ability to stress and relax, there was no problem anymore, players made their own ideas by removing or unusual gripping of a chair - a cannon, a computer, a typewriter, a car, a wheelbarrow, a stroller, a boat, a dog-kennel, a dancing partner, a wheelchair. We can mention an example which talks about a continuous social problem. A schoolgirl had a problem to express "a wheelchair", she whispered: "But I am ashamed for the idea, I am not going to say it aloud". She was ashamed to express something what is natural for somebody else. Many pupils still perceive health disability as an inner communicational barrier. In the current social and school environment conditions for inclusion are still not created. With solving this social problem we should start during the preparation of future teachers. We believe that our solved task at the Department of Education of the Pedagogical Faculty of Constantine the Philosopher University in Nitra will contribute to it. The Department of Education participated in the project by means of professional consultation and cooperation at workshops. The mentioned solved task was supported by the Ministry of Education, Science, Research and Sport within KEGA (Cultural and Educational Grant Agency). The solved task was 
titled "Creating Inclusive Environment in the Conditions of a University" KEGA: 052 UKF - 4/2011).

At the penultimate meeting we announced that we would perform in the theatre on a real stage and we would not have any scenarios, we would improvise on the set topic and it would be based on the exercises which we had carried out during our meetings. It was interesting to see what an undisciplined listening began in the group of children. All the children started to willingly and carefully cooperate. We set the order of the exercises which might be presented on the stage together and we linked them with the topic-Circus.

In conclusion, we would like to mention that in the introduction of our last meeting, the children were listening to the instructions of the lecturer for the first time and they showed respect. As an example, there was an instruction to put aside the tools we were playing with. It was a pleasure to observe children following the rules we set, and what is more, for no need for disciplining them. Furthermore, they sorted tools not only according to shapes, but also according to colours and they cooperated with each other. We are sure that these positive result were achieved by the systematic approach without disciplining children from the side of the teacher but also by the fact that pupils realized that the teacher is interested in their opinions, interests, and respects them, he/she can creatively include them in a communicational game without the intention showing them that he/she can do it better. Pupils consequently found out that if we do not shout over and no warnings are need we have time to do more activities. It motivated them to following rules and to discipline. It is a positive finding because when we began with the meetings it was not possible to talk about rules or discipline, it was mostly about shouting over, obloquy, sassing, using vulgarisms, refusing games, and it took a long time until we started any creative activity.

Within the final reflections we were interested in the meaning of our meetings for the children: - It is fun for us. - It is good here. - I do not know, I do not want to answer. It is different than at school despite we are at school. - I don't have to worry about anything at school. - I feel like when I am at greatgrandmother's, very well. - It is superb. - It is like a poem. I like writing them. Most of these pupils were labelled unsuccessful, it was fascinating to find out when it started. Many of them agreed that it started in the fifth grade. Their statements: - I had only one three and now I have six fours.

Children/pupils need to be positively assessed, those successful as well as the less successful ones. Everyone of them makes an effort to be excellent at something, to surprise somebody but it does not work every time. And if so, it often stays unnoticed because it is a banality for adults. Children see their parents like this: "At home, they instruct us, criticize us, but they do not praise us.

Teachers should not forget about the importance of the phenomenon of students 'appraisal. We praised the children very often. As we had promised at the 
beginning, their opinions were respected and they were not mocked. To test what children feel when being appraised we used The street of admiring. We made a golden gate and all the children walked through it. Other players were telling different words of praise. At the end we appraised all the children for taking part in the games and exercises, and improvisation we did together.

There were moments when children forgot about disrupting by their comments and they were listening. We reminded them: "Now it is perfect, you listen to me. Why?" Children responded: "Because we have found out that you are.... that we will not mess anything up....you want to work with us." Again, it is confirmed that a pedagogue should be interested in children he works with. Lessons are not only about explaining from the side of an adult to a child or about acting unnaturally and pretending self-importance. People are the main actors of the educational process. Therefore, the process should acquire mainly a human dimension. Then there is the assumption that pupils will be willing to cooperate and to respect all the rules which we create during the lessons.

\section{Conclusion, or by creative drama to removing communicational barriers}

The purpose of the project was to offer the integrated pupils with different types of disorders special care in the form of stimulation and diverse supportive therapies, to make them more resistant to the effects to which they are daily exposed at school or in the family environment.

The uniqueness of meetings with integrated pupils is seen in the opportunity to find out what the real qualities of these pupils are. The pupils had the opportunity to discover something what is interesting for them, something in what they are better than at learning. We see the sense in the fact that after finishing the project they can develop (discover) new interest and it can also be a challenge for the school to include particular interesting activities into the educational activity. Based on the realized workshops and the performance on the theatre stage in front of audience we dare to claim that including similar activities regularly may significantly help the pupils to develop their communication skills and their own personalities. Last but not least, it will help the teachers and we think that it will also help the class and school atmosphere. We agree with M. Pasch (1998) who noted that for successful education we need more than to know good techniques. The author takes the view that teachers who think about their teaching methods and procedures are better professionals than those who do not. E. Petlák (2000) states that the success of pedagogical interactions is mainly determined by teachers' skills and tendency to think about themselves and their pedagogical work, to analyse it, see its benefits and deficiencies, to sturdily remove deficiencies, to be able to generalize own 
experiences and to use the experiences of other skilled teachers creatively. As K. Rýdl (2003) reminds us, teachers must realise that the key to teaching is not the answer, but the question. It will no longer be expected to know only one correct answer. Teachers will be expected to incite the curiosity of every pupil and they will help pupils to discover new things and work systematically. We may say that also teachers' thinking is an important determinant of the quality of education. Teachers' behaviour, presentation, communication and expressing the opinions are based on their thinking. It is also assumed that a teacher should be an emotionally stable, flexible person willing to try new pedagogical and didactic procedures. C.A. Klaassen (2002) from the University in Nijmegene, Netherlands, notes the problematic phenomenon that occurs more often in Western European countries - it is the erosion of pedagogical sensitivity of teachers. They are not prepared to talk about the pedagogical aspects of their work - about their approach to pupils on relational, personal or moral level. They have the problem to talk about pedagogical problems with parents because of the emotional difficulty of this communication caused by the lack of a clear pedagogical vision in their work. Research in which Klaasen participated showed that there is an increasing proportion of teachers who are afraid of moral topics which may appear in the classrooms and who avoid situations in which they should enter the discussion with pupils. Exactly here we see the place for the method of creative drama and its contribution for teachers.

\section{References}

BARHAM, M.: Dramatherapy : The Journey to becoming aprofession Dramatherapy. vol. 17, n. 1, Summer 1995.

BLÁHOVÁ, K.: Uvedeni do systému školni dramatiky. Praha : IPOS, 1996.

FENYVESIOVÁ, L.: Proces učenia žiakov ako determinant výberu vyučovacích metód. In: PERHÁCS, J. et al.: Nové pohl'ady na edukačné vedy. Nitra: PF UKF, 2004.

GOLEMAN, D.: Emoční inteligence. Praha: Columbus, 1997.

KLAASSEN, C. A.: Teacher pedagogical competence and sensibility. In Teaching and Teacher Education. vol. 18, n. 2, February 2002, p. 151 158.

KOŤÁTKOVÁ, S.: Vybrané kapitoly z dramatické výchovy. Praha: Karolinum, 2008.

KOVÁČOVÁ, B.: Práca s bábkou. Bratislava: UK, 2011.

MACHKOVÁ, E.: Metodika dramatické výchovy. Praha: ARTAMA, 2007.

MAJZLANOVÁ, K.: Dramatoterapia v liečebnej pedagogike. Bratislava: IRIS, 2004. 
O'NEILL, C. - LAMBERT, A.: Drama structures. In MACHKOVÁ, E.: Úvod do studia dramatické výchovy. Praha: ARTAMA, 1998.

PASCH, M. et. al.: Od vzdělávacího programu $k$ vyučovaci hodině. Praha: Portál, 1998.

PETLÁK, E.: Pedagogicko-didaktická práca učitela. Bratislava: IRIS, 2000.

RÝDL, K.: Inovace školských systémů. Praha: ISV, 2003.

SEIDLER, P. - KURINCOVÁ, V.: Inakosti v edukačnom prostredí. Nitra: PF UKF, 2005.

STANISLAVSKIJ, K. S.: O hercovej práci. Bratislava: Tália-press, 1997.

VALENTA, M. et. al.: Dramatika pro speciální pedagógy. Olomouc: PF UP, 2001.

ZELINA, M. Alternatívne školstvo. Bratsilava: IRIS, 2000. 